\title{
KECERNAAN PROTEIN KASAR DAN LEMAK KASAR PADA SAPI PERAH PERANAKAN FH (FRIESIAN HOLSTEIN) YANG DIBERI PAKAN LENGKAP BERBASIS TEBON JAGUNG
}

\author{
Diwi N. Y. Polii, M. R. Waani*, A. F. Pendong
}

Fakultas Peternakan Universitas Sam Ratulangi Manado

\begin{abstract}
ABSTRAK
Penelitian ini bertujuan untuk mengetahui konsumsi dan kecernaan protein kasar dan lemak kasar pakan lengkap berbasis tebon jagung. Ternak yang digunakan adalah 14 ekor sapi perah FH dengan berat 300-400 kg. Penelitian ini menggunakan analisis uji $\mathrm{T}$ keragaman tidak sama. Perlakuan terdiri dari $\mathrm{Ra}=30$ $\%$ konsentrat $+70 \%$ tebon jagung dan $\mathrm{Rb}=$ $30 \%$ konsentrat $+35 \%$ tebon jagung $+35 \%$ rumput raja. Variabel yang diamati adalah konsumsi protein kasar, konsumsi lemak kasar, kecernaan protein kasar dan kecernaan lemak kasar. Hasil analisis uji $\mathrm{T}$ menunjukkan, konsumsi protein kasar $\mathrm{Ra}$ (934,23 gram/ekor/hari) berbeda tidak nyata $(\mathrm{P}>0,05)$ dengan $\mathrm{Rb} \quad(924,20$ gram/ekor/hari), demikian juga dengan konsumsi lemak kasar $\mathrm{Ra} \quad(332.93$ gram/ekor/hari) berbeda tidak nyata ( $\mathrm{P}>0,05)$, dengan perlakuan $\mathrm{Rb}(350,66$ gram/ekor/hari). Kecernaan protein kasar pada perlakuan $\mathrm{Rb}(85,34 \%)$ nyata $(\mathrm{P}<0,05)$ lebih tinggi dibanding $\mathrm{Ra}(82,18$ $\%)$ dan kecernaan lemak kasar perlakuan $\mathrm{Rb}(88,90 \%)$ sangat nyata $(\mathrm{P}<0,01)$ lebih tinggi dibanding $\mathrm{Ra}(84,31 \%)$. Disimpulkan bahwa pemberian pakan lengkap terdiri dari konsentrat, tebon jagung, dan rumput raja memiliki nilai kecernaan protein kasar dan lemak kasar yang lebih baik dibandingkan pakan lengkap yang terdiri dari konsentrat dan tebon jagung.
\end{abstract}

Kata Kunci: kecernaan, protein kasar, lemak lasar, pakan lengkap, sapi FH.

\footnotetext{
*Korespondensi (Corresponding author)

Email: mercy_yanti@yahoo.com
}

\begin{abstract}
ABSTRAK
THE DIGESTIBILITY OF CRUDE PROTEIN AND CRUDE FAT ON FRIESIAN HOLSTEIN (FH) DAIRY COW FED COMPLETE FEED BASED ON CORN FORAGE. This study aims to determine the intake and digestibility of the crude protein and crude fat of complete feed based on corn forage. $14 \mathrm{FH}$ dairy cows with $300-400 \mathrm{~kg}$ of weight were used in this study. This study was arranged in two treatment groups according to t-test (assuming unequal varience). The treatments consisted of $\mathrm{Ra}=$ $30 \%$ concentrate $+70 \%$ corn forage and $\mathrm{Rb}$ $=30 \%$ concentrate $+35 \%$ corn forage + $35 \%$ king grass. The variables measured were crude protein and crude fat intakes, and crude protein and crude fat digestibilities. t-test analysis results showed, the crude protein intake of $\mathrm{Ra}$ (934.23 grams/head/day) was not significantly different $(\mathrm{P}>0.05)$ from $\mathrm{Rb}$ (924.20 grams/head/day), as well as the crude fat intake of $\mathrm{Ra}$ (332.93 grams/head/day) was also not significantly different $(\mathrm{P}>0.05)$ form $\mathrm{Rb} \quad(350.66$ grams/head/day). The digestibility of crude protein in $\mathrm{Rb}$ treatment $(85.34 \%)$ was significantly $(\mathrm{P}<0.05)$ higher than $\mathrm{Ra}$ $(82.18 \%)$, while the digestibility of crude fat in $\mathrm{Rb}$ treatment $(88.90 \%)$ was highly significant different $(\mathrm{P}<0.01)$ from $\mathrm{Ra}$ $(84.31 \%)$. It is concluded that complete feed consisting of concentrate, corn forage and king grass has better crude protein and crude fat digestibilities than the other one that just consisting concentrate and corn forage.
\end{abstract}


Keywords: digestibility, crude protein, crude fat, complete feed, FH cows.

\section{PENDAHULUAN}

Di Indonesia, pada kondisi iklim yang berada di dataran tinggi mendukung untuk mengembangkan usaha peternakan sapi perah, sebagai sumber penghasil susu guna penyediaan pangan sumber protein. Sapi perah yang banyak dipelihara di Indonesia adalah sapi perah Friesian Holstein (FH), dimana produksi susu di dalam negeri baru memenuhi sekitar $35 \%$ dari kebutuhan nasional. Produksi susu segar di dalam negeri dihasilkan dari sekitar 495.089 ekor sapi perah bangsa $\mathrm{FH}$ yang memproduksi susu (DITJENNAK, 2015).

Sapi perah mengkonsumsi pakan yang terdiri dari bahan pakan kasar (hijauan) dan bahan pakan pelengkap (konsentrat). Rumput raja (Pennisetum purpupoides) adalah jenis rumput hasil persilangan antara Pennisetum purpureum (rumput gajah) dengan rumput barja Pennisetum typhoides (Suyitman, 2014). Produksi rumput raja cukup tinggi yaitu 200-250 ton/hektar/tahun (Rukmana, 2005 disitasi oleh Nasriya et al., 2016). Rumput raja mempunyai kandungan TDN 57,50\%, Ca 0,37\%, P 0,39\% (Sutardi, 1981), neutral detergent fiber (NDF) 76,22\%, dan acid detergent fiber (ADF) 46,75\% (Siswanto et al., 2016). Selain rumput raja, tebon jagung juga sering dimanfaatkan sebagai pakan ternak. Tebon jagung merupakan pakan yang sangat bermanfaaat bagi kehidupan ternak karena hampir keseluruhan dari tanaman ini dapat dimanfaatkan. Hijauan jagung mempunyai kandungan PK 12,06\%, SK 25,2\%, Ca 0,28 dan P 0,23\% (Heryanto et al., 2016). Pakan yang diberikan pada sapi perah harus diperhatikan kualitas dan kuantitasnya, karena akan berpengaruh pada produksi susu. Umumnya nilai nutrisi yang terkandung dalam hijauan di daerah tropis rendah, sehingga diperlukan pakan penguat (konsentrat) untuk mencukupi kebutuhan ternak.

Jumlah konsumsi pakan merupakan faktor paling penting karena terkait dengan zat-zat makanan yang dibutuhkan ternak untuk berproduksi. Konsumsi pakan pada ternak ruminansia sangat komplek dan banyak faktor yang terlibat seperti sifatsifat pakan, faktor ternak, dan faktor lingkungan (Tomaszewska et al., 1993).

Tingkat kecernaan nutrien pakan dapat menentukan kualitas dari ransum tersebut. Besarnya kecernaan menentukan banyaknya nutrien yang dapat dimanfaatkan untuk memenuhi kebutuhan hidup pokok dan pertumbuhan (Widya et al., 2008; Sondakh et al., 2018; Tulung et al., 2020).

Protein kasar merupakan salah satu zat makanan yang sangat dibutuhkan oleh 
ternak. Jumlah protein yang dibutuhkan sapi perah tergantung pada ukuran tubuh, pertumbuhan, produksi susu dan tahap kebuntingan.

Lemak adalah unsur utama hewan dan merupakan sumber energi tersimpan yang penting. Lemak kasar berfungsi sebagai sumber energi yang berdensitas tinggi. Asam lemak akan menghasilkan energi yang lebih tinggi dibandingkan dengan nutrien lain seperti karbohidrat atau protein ketika dimetabolisme dalam tubuh (Wina dan Susana, 2013). Tujuan penelitian ini adalah untuk mengetahui kecernaan protein kasar dan lemak kasar pada ternak sapi perah yang diberikan pakan lengkap berbasis tebon jagung pada sapi FH.

\section{MATERI DAN METODE PENELITIAN}

Penelitian ini dilaksanakan di Unit Pelaksana Teknis Daerah (UPTD) Pembibitan Ternak dan Hijauan Pakan Provinsi Sulawesi Utara Tampusu Kecamatan Remboken Kabupaten Minahasa.

Penelitian ini menggunakan 14 ekor ternak sapi perah $\mathrm{FH}$ dengan umur 7-8 tahun dengan berat 300 - $400 \mathrm{~kg}$. Kandang yang digunakan adalah kandang individual sebanyak 14 kandang yang dilengkapi dengan tempat pakan dan tempat minum.
Pakan yang digunakan adalah rumput raja (Pennisetum purpupoides), tebon jagung dan konsentrat. Pakan konsentrat disusun dari bahan - bahan pakan yaitu jagung, dedak halus, bungkil kedelei, bungkil kelapa, tepung ikan, premix (suplemen, vitamin, mineral) dan garam. Penggunaan $30 \%$ konsentrat dan $70 \%$ pakan hijauan, didasarkan pada kebutuhan ternak sapi perah dengan bobot badan rata-rata $300 \mathrm{~kg}$, dengan kebutuhan bahan kering 7,5 kg (NRC, 2001). Komposisi nutrien bahan pakan yang digunakan serta formulasi ransum dapat dilihat pada Tabel 1 dan 2 .

\section{Metode Penelitian}

Penelitian ini adalah penelitian eksperimen dengan menggunakan metode koleksi total terdiri dari 2 perlakuan masing-masing 7 ulangan. Perlakuan yang diterapkan adalah: $\mathrm{Ra}=30 \%$ konsentrat + $70 \%$ tebon jagung $\mathrm{Rb}=30 \%$ konsentrat + $35 \%$ rumput raja $+35 \%$ tebon jagung.

\section{Tatalaksana Penelitian}

Pelaksanaan penelitian ini dibagi menjadi 3 tahap yaitu tahap pendahuluan, tahap pra koleksi dan tahap koleksi.

\section{Tahap Pendahuluan}

Pada awal penelitian ternak diberikan kesempatan untuk beradaptasi dengan pakan perlakuan. Adaptasi pakan dilakukan selama 7 hari. Adaptasi 
Tabel 1. Komposisi Nutrien Pakan Percobaan

\begin{tabular}{lccc}
\hline \multirow{2}{*}{ Nutrien *) } & Konsentrat & Tebon Jagung (TJ)* & Rumput Raja (RR)** \\
\cline { 2 - 4 } & \multicolumn{3}{c}{$\%$} \\
\hline Bahan Kering & 87,93 & 19,73 & 20,30 \\
Protein Kasar & 16,65 & 10,90 & 9,52 \\
Lemak Kasar & 10,75 & 2,17 & 3,14 \\
Serat Kasar & 11,23 & 33,21 & 31,26 \\
NDF & 27,23 & 69,81 & 73,52 \\
ADF & 14,39 & 40,20 & 44,49 \\
Ca & 0,73 & 0,39 & 0,35 \\
P & 1,82 & 0,23 & 0,28 \\
Abu & 9,11 & 7,67 & 9,38 \\
BETN & 40,48 & 46,05 & 44,98 \\
Energi Bruto (Kkal) & 3708,89 & 3791,00 & 3375,00 \\
\hline
\end{tabular}

Keterangan : * Menurut Tulung et al. (2020) ** Lab. Minat Nutrisi dan Makanan Ternak Fak. Peternakan UB (2019)

Tabel 2. Formulasi Pakan Perlakuan dan Komposisi Nutrien

\begin{tabular}{lcc}
\hline \multirow{2}{*}{ Bahan Pakan $(\%)$} & \multicolumn{2}{c}{ Perlakuan } \\
\cline { 2 - 3 } & $\mathrm{Ra}$ & $\mathrm{Rb}$ \\
\hline Konsentrat & 30 & 30 \\
Rumput Raja & 0 & 35 \\
Tebon Jagung & 70 & 35 \\
\hline Total & 100 & 100 \\
\hline & & \\
Komposisi Nutrien (\%) & & \\
Protein Kasar & 12,63 & 12,1 \\
Serat Kasar & 26.16 & 25.93 \\
Lemak Kasar & 4,7 & 5,04 \\
NDF & 57.03 & 58,32 \\
ADF & 32.45 & 33,95 \\
Ca & 0,48 & 0,46 \\
P & 0.40 & 0,41 \\
\hline
\end{tabular}

Keterangan : Dihitung berdasarkan Tabel 1

dilakukan dengan tujuan untuk membiasakan ternak mengkonsumsi pakan perlakuan dan mengetahui konsumsi pakan bebasnya, dimana dilakukan pengambilan dan konsumsi. Pakan diberikan secara ad libitum serta air minum disediakan setiap saat. Sebelum diberikan ke ternak, tebon jagung dan rumput raja dicacah (Chopper) terlebih dahulu dengan ukuran $\pm 5 \mathrm{~cm}$. 
Konsumsi ternak dihitung dari konsumsi bahan kering.

\section{Tahap Pra-Koleksi}

Tiga hari sebelum pengambilan data dan koleksi, dilakukan pembatasan pemberian pakan sebanyak $80 \%$ dari rataan konsumsi pakan pada tahap pendahuluan. Pembatasan pakan dilakukan agar pakan yang diberikan dapat dikonsumsi secara keseluruhan dan tidak tersisa.

\section{Tahap Koleksi}

Pengukuran kecernaan ini berdasarkan metode koleksi total. Pada tahap ini, pakan tetap diberikan sebanyak $80 \%$. Feses ditimbang setiap defikasi dan diambil sampel 5\% untuk analisis. Pengumpulan feses dilakukan selama 5 hari. Pada periode ini diambil sampel pakan dan feses untuk dianalisis di laboratorium. Pengambilan sampel dilakukan setiap hari selama tahap koleksi. Feses kemudian dikeringkan dengan dijemur hingga mencapai berat kering. Sampel yang sudah dikeringkan dari setiap sapi dikomposit dan diambil 100 gram untuk dianalisis protein kasar dan lemak kasar.

\section{Variabel yang Diamati}

1. Konsumsi protein kasar: selisih antara protein kasar dalam pakan yang diberikan dengan protein kasar dalam pakan sisa.
2. Konsumsi lemak kasar: selisih antara lemak kasar dalam pakan yang diberikan dengan lemak kasar dalam pakan sisa.

3. Kecernaan protein kasar (KcPK)

$\mathrm{KcPK}=\frac{\text { Konsumsi } P K-P K \text { Feses }}{\text { Konsumsi } P K} \times 100 \%$

4. Kecernaan lemak kasar

$\mathrm{KcLK}=\frac{\text { Konsumsi } L K-L K \text { Feses }}{\text { Konsumsi } L K} \times 100 \%$

\section{Analisis data}

Penelitian ini menggunakan analisis uji $\mathrm{T}$ dua contoh dengan ragam tidak sama (t-test two sample assuming unequal varience) (Snedecor dan Cochran, 1989;

Derrick, et al. 2017).

Rumus t-test : $t=\frac{\bar{x}_{1-\bar{x}_{2}}}{\sqrt{\frac{\sigma_{2}^{2}}{n_{2}}+\frac{\sigma_{2}^{2}}{n_{2}}}}$ dimana: $\mathrm{t}=\mathrm{t}$ statistik

$\bar{x}_{1}$ dan $\bar{x}_{2}=$ rataan hasil dari dua contoh perlakuan

$\sigma^{2}{ }_{1}$ dan $\sigma^{2}{ }_{2}=$ keragaman dari hasil kedua contoh perlakuan

$\mathrm{n}_{1}$ dan $\mathrm{n}_{2}=$ jumlah pengamatan dari 2 perlakuan $\mathrm{t}$ - statistik mengikuti suatu distribusi $\mathrm{t}$, dengan perkiraan derajat bebas (df), sebagai berikut:

$$
d f=\frac{\left(\sigma^{2}{ }_{1} / n_{1}+\sigma^{2}{ }_{2} / n_{2}\right)^{2}}{\left(\sigma^{2}{ }_{1} / n_{1}\right)^{2} /\left(n_{1}-1\right)+\left(\sigma^{2}{ }_{2} / n_{2}\right) /\left(n_{2}-1\right)}
$$




\section{HASIL DAN PEMBAHASAN}

Hasil penelitian tentang kecernaan protein kasar dan lemak kasar pada sapi perah peranakan $\mathrm{FH}$ yang diberi pakan lengkap berbasis tebon jagung dapat dilihat pada Tabel 3.

\section{Konsumsi Protein Kasar}

Pada Tabel 3 memperlihatakan bahwa rerata konsumsi protein kasar perlakuan Ra sebesar 934,23 g/ekor/hari dan perlakuan $\mathrm{Rb}$ sebesar 924,20 g/ekor/hari. Hasil analisis uji $\mathrm{T}$ menunjukkan bahwa perlakuan memberikan perngaruh yang berbeda tidak nyata $(\mathrm{P}>0,05)$ terhadap konsumsi protein kasar pada sapi perah FH.

Hasil penelitian ini lebih tinggi dari yang dilaporkan Cahyono et al. (2015) melakukan penelitian tentang kecernaan nutrisi konsentrat- PUFA yang mengandung Curmiyeast pada sapi perah laktasi, yang menggunakan pakan rumput alam dan konsentrat PUFA yang berbeda memperoleh hasil konsumsi protein kasar berkisar 780-720 g/ekor/hari. Perbedaan konsumsi protein kasar pada penelitian ini dengan para peneliti lain kemungkinan disebabkan perbedaan kandungan nutrien pakan perlakuan. Menurut Kamal (1997) bahwa banyaknya pakan yang dikonsumsi akan mempengaruhi besarnya nutrien lain yang dikonsumsi, sehingga semakin banyak pakan yang dikonsumsi akan meningkatkan konsumsi nutrien lain yang ada dalam pakan.

\section{Konsumsi Lemak Kasar}

Rerata konsumsi lemak kasar (Tabel 3) memperlihatkan bahwa konsumsi lemak kasar pada perlakuan Ra sebesar 332,93 g/ekor/hari dan perlakuan $\mathrm{Rb}$ sebesar 350,66 g/ekor/hari. Hasil analisis uji $\mathrm{T}$ menunjukkan bahwa perlakuan memberikan pengaruh berbeda tidak nyata $(\mathrm{P}>0,05)$ terhadap konsumsi lemak kasar pada sapi perah FH. Hasil penelitian Setianingtyas et al. (2014) yang melakukan penelitian tentang tampilan lemak kasar dan bahan kering tanpa lemak pada susu sapi perah akibat pemberian ransum dengan imbangan hijauan dan konsentrat yang berbeda, menggunakan pakan rumput gajah dan konsentrat yang berbeda memperoleh hasil konsumsi lemak berkisar 400 - 440 g/ekor/hari. Hasil penelitian ini lebih rendah dibandingkan dengan penelitian dari Setianingtyas et al. (2014). Perbedaan hasil penelitian kemungkinan disebabkan karena perbedaan kandungan nutrien pakan perlakuan. Menurut Thomaszewska et al. (1993) disitasi oleh Thomas et al. (2014) menyatakan bahwa tingkat konsumsi sangat dipengaruhi oleh koefisien cerna, kualitas pakan, fermentasi dalam rumen serta status fisiologi ternak. 
Tabel 3. Rerata Konsumsi dan Kecernaan Protein Kasar dan Lemak Kasar Pakan Lengkap Berbasis Tebon Jagung

\begin{tabular}{lcc}
\hline \multicolumn{1}{c}{ Parameter } & \multicolumn{2}{c}{ Perlakuan } \\
\hline & $\mathrm{Ra}$ & $\mathrm{Rb}$ \\
\cline { 2 - 3 } Konsumsi Protein Kasar (gr/ekor/hari) & 934,23 & 924,20 \\
Konsumsi Lemak Kasar (gr/ekor/hari) & 332,93 & 350,66 \\
Kecernaan Protein Kasar (\%) & $82,18^{\mathrm{a}}$ & $85,34^{\mathrm{b}}$ \\
Kecernaan Lemak Kasar (\%) & $84,33^{\mathrm{a}}$ & $88,90^{\mathrm{b}}$ \\
\hline Keterangan: Superskrip yang berbeda pada baris yang sama menunjukkan perbedaan yang
\end{tabular}

Keterangan: Superskrip yang berbeda pada baris yang sama menunjukkan perbedaan yang sangat nyata $(\mathrm{P}<0,01)$

\section{Kecernaan Protein Kasar}

Rerata kecernaan protein kasar (Tabel 3) memperlihatkan bahwa kecernaan protein kasar pada perlakuan $\mathrm{Ra}$ sebesar $82,18 \%$ dan perlakuan Rb sebesar $85,34 \%$. Hasil analisis uji $\mathrm{T}$ menunjukkan bahwa perlakuan memberikan pengaruh yang berbeda sangat nyata $(\mathrm{P}<0,01)$. Kecernaan protein kasar perlakuan Rb lebih tinggi dari Ra. Tingginya kecernaan protein pada $\mathrm{Rb}$ kemungkinan disebabkan oleh kandungan protein kasar seperti tercantum pada Tabel 2. Kandungan protein kasar pada Tabel 2, Ra 12,6\% lebih tinggi dari kandungan protein kasar pada perlakuan $\mathrm{Rb}$ yang hanya $12,1 \%$. Rendahnya kandungan protein kasar pada perlakuan $\mathrm{Rb}$ dapat menyebabkan peningkatan daya cerna protein kasar $\mathrm{Rb}$ oleh karena adanya efek asosiasi positif dari pakan penyusun perlakuan $\mathrm{Rb}$. Menurut Tuturoong et al. (2014) daya cerna campuran bahan pakan tidak selalu sama dengan rata-rata daya cerna komponen bahan-bahan yang menyusun hal ini disebut efek asosiasi pakan. Protein kasar yang mudah larut dapat menyebabkan mudah terdegradasi di dalam rumen sehingga yang lolos hanya sedikit dibandingkan protein yang tidak mudah larut. Kelarutan protein kasar yang tinggi dalam rumen merupakan penyebab tidak efisiennya pemanfaatan protein kasar pakan yang dikonsumsi ternak (Richard dan Van Soest, 1977) sementara protein yang tidak mudah larut memiliki peluang untuk masuk kedalam saluran cerna pascarumen, menyebabakan protein tersebut dapat dicerna serta diestimasi dan diserap secara efisien.

Penelitian Sarah et al. (2015) tentang kecernaan protein kasar ransum sapi perah dengan pemberian imbangan hijauan dan konsentrat yang berbeda memperoleh hasil kecernaan protein berkisar 62,03\% - 67,48\%. Hasil penelitian ini lebih tinggi dibandingkan dengan penelitian dari Sarah et al. (2015). Perbedaan daya cerna protein lebih 
disebabkan pada perbedaan kandungan nutrien pakan perlakuan. Menurut Suardin et al. (2014) bahwa faktor yang mempengaruhi terhadap kecernaan ditinjau dari segi pakan kecernaan dipengaruhi oleh perlakuan terhadap pakan (pengolahan, penyimpanan dan cara pemberian) jenis, jumlah dan komposisi pakan yang diberikan pada ternak.

\section{Kecernaan Lemak Kasar}

Rerata kecernaan lemak kasar pakan (Tabel 3) memperlihatkan bahwa perlakuan $\mathrm{Ra}$ sebesar $84,31 \%$ dan kecernaan lemak pada perlakuan $\mathrm{Rb}$ sebesar 88,90\%. Hasil analisis uji $\mathrm{T}$ menunjukkan bahwa perlakuan memberikan pengaruh yang sangat nyata $(\mathrm{P}<0,01)$. Kercernaan lemak kasar pakan lengkap yang menggunakan tebon jagung, rumput raja dan konsentrat lebih tinggi dibandingkan pakan yang hanya menggunakan tebon jagung dan konsentrat.

Kecenderungan suatu kecernaan bahan pakan ditunjukkan oleh komposisi kimia pakan. Bahan pakan dengan kandungan lemak yang tinggi akan mempunyai kecernaan yang rendah. Walaupun kandungan lemak kasar perlakuan $\mathrm{Rb}$ lebih tinggi dibanding $\mathrm{Ra}$ (Tabel 2) namun kecernaan lemak kasar perlakuan $\mathrm{Rb}$ lebih tinggi dibanding $\mathrm{Ra}$. Hasil penelitian ini lebih disebabkan oleh efek asosiasi nutrien dari bahan pakan perlakuan. Menurut Tilman et al. (1998) bahwa daya cerna suatu bahan pakan juga tergantung pada keserasian zat-zat makanan yang terkandung di dalamnya dikenal dengan nama efek asosiasi. Menurut Sastrawan (2009) bahwa kemampuan kecernaan suatu pakan tergantung pada kualitas zat makanan yang terdapat di dalam pakan sehingga berpengaruh terhadap pertumbuhan mikroorganisme. Tingginya daya cerna lemak kasar disebabkan oleh struktur kimia lemak yang mudah dicerna (Wiseman, 1990).

Mastopan et al. (2013) melakukan penelitian menggunakan ransum yang mengandung pelepah daun kelapa sawit dengan perlakuan fisik, kimia, biologis menghasilkan kecernaan lemak kasar dan kombinasinya pada domba yang berkisar 92,29\% - 95,76\%. Hasil penelitian ini lebih rendah dibandingkan dengan penelitian dari Mastopan et al. (2013). Hal ini diduga karena perbedaan kandungan nutrien pakan perlakuan dan perbedaan jenis ternak. Van Soest (1994) menjelaskan bahwa faktor yang mempengaruhi kecernaan bahan pakan adalah spesies ternak, umur ternak, perlakuan pakan, kadar serat kasar, lignin, pengaruh asosiasi pakan, defisiensi nutrien, komposisi pakan, bentuk fisik pakan, umur tanaman serta lama tinggal dalam rumen. 


\section{KESIMPULAN}

Berdasarkan hasil penelitian ini dapat disimpulkan bahwa pemberian pakan lengkap yang terdiri dari konsentrat, tebon jagung, dan rumput raja memiliki nilai kecernaan protein kasar dan lemak kasar yang lebih baik dibandingkan dengan pemberian pakan lengkap yang menggunakan konsentrat dan tebon jagung.

\section{DAFTAR PUSTAKA}

Cahyono. B. D. E. Sulistyowati, dan I. Badarina. 2015. Kecernaan nutrisi Konsentrat - PUFA yang mengandung curmiyeast pada sapi perah laktasi. Jurnal Sains Peternakan Indonesia 10(1): 59-70.

Derrick, B., B. Russ, D. Toher, dan P. White. 2017. Test statistics for the comparison of means for two samples that include both paired and independent observations. Journal of Modern Applied Statistical Methods 16(1): 137-157.

Direktoral Jendral Peternakan. 2015. Laporan Tahunan Peterbakan dan Kesehatan Hewan Kementrian Pertanianian. Jakarta (ID): Kementrian Pertanian.

Heryanto, K. Maaruf, S.S. Malalantang, M.R. Waani. 2016. Pengaruh pemberian rumput raja (Pennisetum Purpupoides) dan tebon jagung terhadap performans sapi Peranakan Onggole (PO) Betina. Jurnal Zootek 36(1): 123-130.
Kamal, M. 1997. Kontrol Kualitas Pakan. Fakultas Peternakan. Universitas Gadjah Mada, Yogyakarta.

Mastopan., M. Tafsin, N. D. Hanafi. 2013. Kecernaan lemak kasar dan TDN (total digestible nutrient) ransum yang mengandung pelepah daun kelapa sawit dengan perlakuan fisik, kimia, biologis dan kombinasinya pada domba. Jurnal Peternakan Integratif 3(1): 37-45.

Nasriya, R. A. V. Tuturoong, Ch. L. Kaunang, S. S. Malalantang, M. M. Tindangan. 2016. Pengaruh pemberian ransum rumput raja (Pennisetum purpupoides) dan tebon jagung terhadap keorganik pada sapi po pedet jantan. Jurnal Zootek 36(2): 387-394.

National Research Council. 2001. Nutrient Requirements of Dairy Cattle. 7th Revised edition. Washington, DC (US): Natl. Acad. Sci.

Richard, G and P. J. Van Soest, 1977. Protein Solubility of Ruminansia Feeds. Proc. The Cornell Nutrition Conference For Feed Manufacturers. Pp. 91-98.

Sarah, S., T. H. Suprayogi, dan Sudjatmogo. 2015. Kecernaan protein ransum dan kandungan protein susu sapi perah akibat pemberian imbangan hijauan dan konsentrat ransum yang berbeda. Animal Agriculture Journal 4(2): 229-233.

Sastrawan, S. 2009. Pemanfaatan Pelepah Sawit dan Hasil Ikutan Industri Kelapa Sawit Terhadap Kecernaan Bahan Kering dan Bahan Organik Pada Sapi Peranakan Siemental. Skripsi. Universitas Sumatra Utara, Medan. 
Setianingtyas, R. W., Sudjatmogo, dan T. H. Suprayogi. 2014. Tampilan lemak dan bahan kering tanpa lemak pada susu sapi perah akibat pemberian ransum dengan imbangan hijauan dan konsentrat yang berbeda. Animal Agriculture Journal 3(2): 121129.

Siswanto, D., B. Tulung, K. Maaruf, M. R. Waani, M. M Tindangen. 2016. Pengaruh pemberian rumput raja (Pennisetum Purpupoides) dan tebon jagung terhadap Kecernaan NDF dan ADF pada sapi PO pedet jantan. Jurnal Zootek 36(2): 379-386.

Snedecor, G. W. dan W. G. Cochar. 1989. Statistical Methods. 7th Ed. Iowa State University Press, Ames, Iowa.

Sondakh, E.H.B., M.R. Waani, J.A.D. Kalele, dan S.C. Rimbing. 2018. Evaluation of dry matter digestibility and organic matter of in vitro unsaturated fatty acid based ration of ruminant. International. J. current adv. Res. 7(6): 13582-13584

Suardin, S., N. Sandiah, R. Aka. 2014. Kecernaan bahan kering dan bahan organik campuran rumput mulato (Brachiria Hybrid.Cv Mulato) dengan jenis legum berbeda menggunakan cairan rumen sapi. Jurnal Ilmu dan Teknologi Peternakan Tropis 1(1): 16-22.

Sutardi, T. 1981. Sapi Perah dan Pemberian Makanannya. Bogor (ID): Institut Pertanian Bogor. Bogor

Suyitman. 2014. Produktivitas rumput raja (Pennisetum Purpupoides) pada pemotongan pertama menggunakan beberapa sistem pertanian. Jurnal Peternakan Indonesia 16(2): 119-127

Thomas, J. V. S., M. Tafsin., A. H. Daulay. 2014. Kecernaan bahan kering dan bahan organik ransum yang mengandung pelepah daun kelapa sawit dengan perlakuan fisik, kimia, biologis dan kombinasinya pada domba. Jurnal Peternakan Integratif 3(1): 62-70.

Tilman, A. D., S. Reksohadiprodjo, H. Hartadi, S. Prawirokusumo dan S. Lebdoseokojo. 1998. Ilmu Makanan Ternak Dasar. Cetakan Ke- 6, Gadjah Mada University Press, Yogyakarta.

Tomaszewska, M. W., I. M Mastika., A Djajanegara., S. Gardiner, dan T. R Wiradarya. 1993. Produksi Kambing dan Domba di Indonesia. UNS pres. Surakarta.

Tulung, Y.L.R., A.F. Pendong, B. Tulung. 2020. Evaluasi nilai biologis pakan lengkap berbasis tebon jagung dan rumput campuran terhadap kinerja produksi sapi Peranakan Ongole (PO). Zootec 40(1): 363 - 379

Tuturoong, R. A. V., Soebarinoto, Hartuti, dan Ch. L. Kaunang. 2014. Evaluasi Nilai Nutrisi dan Rumput Benggala Teramoniasi dan Ampas Sagu Terfermentasi Dalam Pakan Komplit Terhadap Penampilan Kambing Kacang. Disertasi. Universitas Brawijaya Malang.

Van Soest, P.J. 1994. Nutritional Ecology of the The Ruminant. Second. Edition. Comstock Publishing Associates Cornell University Press. A Divisien od Ithaca and London.

Widya, P.L., W.E. Susanto, A.B. Yulianto. 2008. Konsumsi dan kecernaan 
bahan kering dan bahan organik dalam haylase pakan lengkap ternak sapi Peranakan Ongole. Jurnal Media Kedokteran Hewan 24(1): 59 -62 .

Wina, E dan Susana. 2013. Manfaat Lemak Terproteksi Untuk Meningkatkan Produksi dan Reproduksi Ternak Ruminansia. Wartazoa. Bogor. 23(4): 176-184.

Wiseman, J. 1990. Variability in the Nutritive Value of Fast For Ruminant. In: Feedstuff Evaluatrion. Wiseman, J. And D.J.A.Cole (Eds). Butterworths 